\title{
'Minilivestock' Farming:
}

\section{Who is farming edible insects in Europe and North America?}

\author{
Rhoda Wilkie (University of Aberdeen)
}

An innovative food sector is emerging in North America and Europe: edible insects. Eating insects is not new; farming insects for human consumption is novel. This paper provides an overview of entomophagy to contextualise this upsurge in 'minilivestock' farming. It also charts the rise of 'feeder' insect farms because their ability to mass rear invertebrates, for exotic pets, reptiles and other insectivores, is of much interest to those starting and intensifying edible insect farms. A descriptive characterisation of frontier farmers will be provided by preliminary profile findings from 17 semi-structured pilot interviews with people with varying experience of rearing feeder and/or food insects. Since conventional livestock workers were the 'forgotten pillar' in agricultural research, this paper affords timely insights into the socio-demographic characteristics, lifestyle interests, and farming experiences of 'entopreneurs' shaping this new 'insect industry'.

Keywords: edible insects; entomophagy; 'minilivestock'; cricket farming; 'entopreneurs' 


\section{Introduction}

The pioneer farms of the new world reared beef herds on the prairie; today the frontier in farming has shifted to high-tech climate-controlled sheds - and the livestock has six legs not four [or two] (Clegg 2015: 1).

About 10 years ago, Professor Sir John Beddington advised the UK Government that 'by 2030 the world will need to produce 50 per cent more food and energy, together with 30 per cent more available fresh water, whilst mitigating and adapting to climate change. This threatens to create a 'perfect storm' of global events' (Wathes et al 2013: 575). At a time of growing critiques about the sustainability of existing livestock farming systems, this narrative of a 'perfect storm' has highlighted global food security issues for politicians and scientists (Delgado et al 1999; van Huis et al 2013; Emel and Neo 2015; Lawrence 2017). To address such environmental and nutritional challenges, an agricultural quest has begun to identify more sustainable livestock production methods and/or alternative sources of food and protein (Rumpold and Schlüter 2013; Sexton 2018). One option, capturing much attention is edible insect farming (Dossey et al 2016a).

At first glance, insects might seem a rather unlikely alternative food. Especially since scientists and chemical companies have expended money, time, and energy during the 20th century to develop 'biocidal agricultural compounds' (pesticides) to systematically kill insects (Rivers 2017: 363). By the 1950s, such insecticides were so effective it contributed to an arable farming 'golden age' whereby, 'Insect pests of agriculture were being controlled, and food production was at an all-time high in terms of yield' (Rivers 2017: 366). On the other hand, Rachel Carson's (1962) book, Silent Spring, raised 
serious questions about the human and environmental safety of chemicals such as DDT (dichlorodiphenyltrichloroethane) which contributed to the United States passing a new National Environmental Policy Act in 1969. This Act 'established the requirement that all chemicals be registered with the federal government before they could be used in the environment or in places where humans would be exposed' (Rivers 2017: 367).

Once again, insects are registering on the environmental radar, this time via a burgeoning entomophagy movement: 'Edible insects are being framed as a panacea for health, resource and climate challenges' (Müller et al 2016:121). ${ }^{1}$ To actualise this salutary vision, insects are being experimentally and/or systematically reared and killed in farms at the vanguard of this invertebrate agricultural revolution. Whilst entomophagists actively rebrand these pesky proteinaceous creatures as bona fide food animals, they also contend farming insects is more sustainable and ethical than conventional forms of livestock production (e.g. van Huis et al 2013; House 2016). Consumers might perceive insect-based food products as 'more 'ethical' than conventional types of meat because of insects' perceived lack of sentience and capacity to suffer' (House, 2016: 55; Tiffin 2016; Barron and Klein 2016; Singer 2016). As one insect eater noted, insects 'are animals, but not animals like the real animals' (House 2016: 55). As liminal animals, insects are 'doubly other - other than humans and other than the animals that we eat as well' (Loo and Sellbach 2013:13). As these authors explain:

Indeed, insect flesh does not contain blood. Tiny, multitudinous, with little recognizable emotion or individual consciousness, they do not easily register as objects of moral obligation or as agents of ethical change. 
Similarly, one of my farming contacts thought 'we think of them [i.e. insects] as something more akin to, you know, tiny machines with a hive mind'. However, having worked with crickets on a daily basis, he now regards them less as 'tiny automata' and more as 'actual living creatures, as animals, you know, that are alive and different'. That being said, Peter Singer (2016) recently suggested there is no urgency to 'launch a campaign for insect rights':

We still do not know enough about insect subjective experiences to do that; and, in any case, the world is far from being ready to take such a campaign seriously. We need first to complete the extension of serious consideration to the interests of vertebrate animals, about whose capacity for suffering there is much less doubt.

From a multispecies perspective, the lesser animal status of insects warrants further investigation. Especially since it is estimated that ' $95 \%-99 \%$ of the planet's animal species are invertebrates, leading them to be called the "silent majority" (Moore 2017: 166). Although scholars have studied non-vertebrate animals (e.g. Bingham 2006; Beisel et al 2013; Bull 2014), much of Human-Animal Studies, to date, has focused on human-mammal relations (e.g. Lunney 2014; Clark 2016). Given this tendency, might interspecies scholarship be characterised by 'institutional vertebratism' or a 'bias against animals without backbones' (Leather 2009: 4013-14)?

In 2009, Simon Leather first used the notion of 'institutional vertebratism' in a letter he sent to Trends in Ecology and Evolution. As an entomologist, he expressed concern about a seeming 'bias against animals without backbones' that could impact on UK food security (Leather 2009: 4013-14). The nature of his concerns were evidenced by the 
reduction of entomological Degree courses in the UK and other European countries, the bias to award grants to vertebrate research, and the difficulty of publishing papers about insects in high impact conservation and ecology journals. According to Leather, this professional state of affairs has contributed to 'a dearth of invertebrate knowledge' which threatens future protection and management of food crops (Leather 2009: 413414).

Having contextualised what Leather meant by 'institutional vertebratism', I draw on this notion to highlight how this bias might pertain to edible insect farming in Europe and North America; especially since animal welfare/food regulations are largely characterised by 'institutional vertebratism'. For example, since farm animal welfare laws typically pertain to vertebrate species of food animals it is unclear how applicable existing regulations are to invertebrate animals and their productive contexts (Erens et al 2012; de Goede et al 2013; Gjerris et al 2016). When this regulatory blind spot is combined with the nominal entomological knowledge/skills of novice farmers entering this new sector (e.g. see Table 1), how well are the needs of productive insects being met in practice.

Since edible insects are a 'novel food' they are also at odds with EU food regulations. That said, a new Novel Food Regulation came into effect from January 2018 that 'aims to streamline the authorisation procedure and to introduce a faster, more proportionate safety assessment for traditional foods from outside the EU with a centralized risk assessment procedure by the EFSA [European Food Safety Authority]' (Belluco et al 2017: 807). Similarly, until 2013, there was a lack of clear guidance from the U.S. 
Food and Drug Administration (FDA). Following consultation with pioneering insect farmers and food producers the FDA produced a document that characterised a 'Human consumption-grade-insect':

insect[s] marketed for human consumption must be farmed specifically for human consumption; that insect food products must be processed, packaged and transported in accordance with current good manufacturing practices (cGMP); and must include a warning label for crustacean or shellfish allergies for consumer safety (Shockley et al 2018: 72).

Whilst food laws undergo clarification, financial investment in 'minilivestock' farming has been impeded. ${ }^{2}$ The lack of expert invertebrate knowledge has further delayed the development of edible insect production (Dobermman et al 2017). Pioneering farmers at the practical hub of these knotty productive-legislative-regulatory gaps are also grappling with such uncertainties. Although conventional farm animal workers were the 'forgotten pillar' in agricultural animal research (English et al 1992: n.p), perhaps experienced insect farmers could play an instructive role from the outset in this fledgling minilivestock sector. For example, having bred, reared and killed invertebrates on a commercial scale, the pragmatic interspecies knowledge of skilled practitioners (including entomologists) could inform, and thus hasten, the development of speciesspecific regulatory frameworks that promote the wellbeing of farmed insects in practice. Although researchers are attending to the challenges of encouraging consumers to eat insects (e.g. Wood and Looy 2000; Looy et al 2014; Deroy et al 2015; Shelomi 2015; Verbeke 2015; Yates-Doerr 2015; House 2016, 2018), less attention has been given to the practitioners who work with insects (except Halloran et al 2017). This omission is noteworthy, because the non-vertebrate status of these atypical farm animals raises a fundamental question; who has the husbandry skills and knowledge to rear and kill 
insects in Europe and North America? Moreover, if people have developed invertebrate husbandry skills/knowledge, how have they acquired them?

This paper begins to address these questions by drawing on preliminary profile findings (e.g. socio-demographic characteristics, lifestyle interests, and farming experience) to provide a descriptive characterisation of those involved in this emerging 'insect industry' (Buiani 2015: 109). This qualitative data has been derived from 17 semi-structured pilot interviews with people in European and North American countries who have varying experiences of rearing feeder and/or food insects. To aid clarification, whilst food insects are suitable for human consumption, 'feeder' insects are typically fed to exotic pets, reptiles and other insectivores (Dossey et al 2016b: 118). As will be explained later, experienced feeder farmers have not only established production templates for the mass rearing of crickets and mealworms, which is of much interest to novice farmers entering the insects-as-food market, they are also well placed to transition into and intensify the production of edible insects. Finally, insects such as black soldier fly are also being intensively produced as an alternative source of feed for farmed animals. ${ }^{3}$ For example, from July 2017, the European Commission allowed 'insect processed animal proteins' (PAPs) in feed for aquaculture animals' (Derrien and Boccuni 2018: 474). This development signals the continued growth of the feed market, as it paves the way for insects-as-feed for other farm animal sectors such as poultry and pigs (e.g. PROteInsect 2016).

Having clarified the differences between food, feeder and feed insects, the pilot profile data discussed in this paper will mainly focus on those involved in the feeder and food 
sectors. ${ }^{4}$ Prior to presenting these profile findings and the methods of research, the next section briefly discusses entomophagy to provide a context for the recent emergence of edible insect farming.

\section{Entomophagy and the rise of edible insect farming}

'In general, most [human] insect-eaters live in tropical or subtropical parts of the world, such as Southeast Asia and sub-Saharan Africa, and most [human] non-insecteaters are from temperate zones, such as Europe, Russia, and northern parts of North America' (Waltner-Toews 2017: 4). Although Jongema (2017) has recorded 2111 edible insect species worldwide and the practices of entomophagy are implemented in different ways, and to varying extents, in approximately 113 countries (House 2018: 10; Dobermann et al 2017: 293), this food practice is not culturally pervasive or readily embraced in Western countries (van Huis et al 2013: xiii). In 'non-insect-eating countries', the very idea of consuming insects is typically viewed with disdain and tends to be associated with 'primitive behaviour' (Payne et al 2016: 271; 35; Rozin \& Fallon, 1987). However, in 1885, a British entomologist called Vincent Holt questioned this prevailing view when he published Why Not Eat Insects? This short pamphlet is 'a manifesto about the culinary delights and ethical good of eating insects, spiders, crustaceans and molluscs' (Loo and Sellbach 2013: 13). In particular, Holt ardently believed entomophagy could augment Victorian diets of labouring families experiencing food poverty at that time (Holt 1995). 
A century later, Gene DeFoliart (1925-2013), regarded as the 'Godfather' of contemporary entomophagy in North America (Shockley et al 2018: 61), has played a similar visionary advocacy role to Holt; albeit DeFoliart identified edible insects as a response to global food insecurity. Based in the University of Wisconsin-Madison Department of Entomology from 1959-1991 (when he retired), from 1978 onwards he conducted 'research and an educational outreach program on the human use of insects as a global food resource' (DeFoliart 2018). An online compendium of DeFoliart's work is on the Insects as Food website; this archive is considered the 'most comprehensive bridge of research from the early twentieth century to the modern era of the entomophagy movement' (Shockley et al 2018: 61). DeFoliart was thus cognisant of how invertebrate dietary practices might contribute to food innovation: the eating of 'sky prawns (grasshoppers)' in Thailand would effectively herald insects as 'the food of the future' (DeFoliart et al 2009: 114).

Since insects were an overlooked nutritional resource this 'galvanise[d] an international movement around investigating entomophagy's potential for developing more sustainable food systems and valorising traditional diets' (Evans et al 2015: 293). This futuristic vision of insects-as-food would gain contemporary resonance, environmental legitimacy and global momentum via promotional literatures written by edible insect enthusiasts, and scientific research in entomology and cognate disciplines in Europe and North America (DeFoliart 1999; Martin 2014; Vantomme 2015; Waltner-Toews 2017). On hindsight, 2010 was a watershed year in North America because 'small groups of advocates and entrepreneurs across the continent realized that they had to shift the conversation on entomophagy' (Shockley et al 2018: 64). By championing the environmental benefits and nutritional credentials of farmed edible insects, 
contemporary pro-entomophagists are offsetting the perception of insects as gimmick and poverty food. Rebranding these pesky proteinaceous creatures in the public imagination has not only stimulated an insect status makeover, the phraseology 'insects as food of the future' has also morphed into a potent ideological mantra in the $21^{\text {st }}$ century.

While eating insects is a longstanding dietary practice, farming edible insects is relatively new (van Huis et al 2013 xiv). ${ }^{5}$ One of the first countries to commercially farm crickets is Thailand. Since 1997, there has been an explosion in cricket farms, with over 20,000 small-scale farmers involved in this new food industry (Halloran et al 2016 and 2017; Hanboonsong et al 2013). Following the publication of the Food and Agriculture Organization's (FAO) Report in 2013: Edible Insects: Future Prospects for Food and Feed Security, insect farming was propelled into the global arena. Since this report has been downloaded over 7 million times to date (Shockley et al 2018: 65), there is clearly an international appetite for, and avid interest in, this nascent food animal agricultural sector. This food-farming trend is manifesting throughout Europe and North America, as evidenced by the number of insect farms springing up to meet this growing demand.

Prior to 2012, no North American farms reared insects for human consumption. Six years later, there are at least 18 farms (Taponen 2018). Although many farms are new start-ups, a few have long reared crickets, and other species of insects for fish bait. Historically, the nonhuman market for crickets originated in the United States following the end of World War II, especially when returning soldiers and other groups of people 
had time to engage in leisure pursuits such as fishing (Dossey et al 2016b: 117-118). In 1947, Armstrong Cricket Farm was the first farm to sell feeder insects commercially in America. However, as new feeder, and less seasonal, markets opened up during the 1970s and 1980s, in response to people keeping, and pet shops selling, exotic pets, reptiles and other insectivores, the market for crickets moved away from fish bait to about ' $80 \%$ live pet feeder insects' (Dossey et al 2016b: 118).

In 2016, this 'industry giant and established pet-feed cricket farm [i.e. Armstrong Cricket Farm] ... announced that they will be converting a small portion of their overall operation to crickets farmed for human consumption, signalling a sea change for other long-time-pet-feed insect farms' (Shockley et al 2018: 69). As feeder farmers tweak business models and physical infrastructures to produce human-grade insects, they are well placed to capitalise on and develop this invertebrate farming sector. Moreover, because these farms have reared insects for over two generations, family members of 'first wave' farmers (as one of my North American interviewees called them) have been socialised into the requisite husbandry skills to breed and raise healthy insect populations on a mass scale. These pioneering descendants have also accrued a wealth of tacit interspecies knowledge in terms of how to work with crickets and other feeder species such as mealworms and grasshoppers. This includes creating and maintaining appropriate breeding environments for non-vertebrate animals (e.g. humidity levels, room temperatures, rearing densities and dietary/watering regimes), recognising and solving problems when they occur, and an ability to interpret species-specific behaviours in these farming contexts. 
The European edible insect-farming scene is similarly built on the back of feeder insect farms. Information collated by the International Platform of Insects for Food and Feed (IPIFF), a non-profit organisation that represents the interests of 'the insect production sector towards EU policy makers, European stakeholders and citizens', shows a preponderance of small and medium-sized companies, many of which are start-ups and a few longer-term businesses (Derrien and Boccuni 2018: 475). The farm businesses with extensive insect rearing experience for 'biocontrol purposes or the production of feed for pet food or zoo animals, [have also] decided to diversify their production activities toward food production or feed production for farmed animals' (Derrien and Boccuni 2018: 471). Insect producers are located in most of the 28 EU Member States, although the Netherlands and France appear to be particularly active countries in terms of the amount of people involved in these sectors and/or the quantities of insects produced therein (ibid: 472). These authors also suggest this 'situation might be explained by the fact that these countries had a longer history of production of insects for ... pet food or zoo animals 'niche markets', Other EU countries with a history of farming feeder insects include 'the Czech Republic, Romania, Spain, Germany, United Kingdom and Belgium' (ibid).

The Netherlands has also become a key "hub" for contemporary edible insect research including, the promotion of entomophagy (House 2018: 6). With over 2111 edible insect species worldwide, the 'Big Four' food species commonly reared in Europe are crickets, mealworms, grasshoppers and buffalo worm (House 2018: 10). Interestingly, a key distinction between entomophagy movements in Europe and North America is the former apparently prefers mealworms whilst the latter prefers crickets (Shockley et al 2018: 70). Although the reason underpinning this difference is not entirely clear, the 
authors note that since crickets were already being commercially farmed for fish bait and pet feed this 'provided a template for the first American and Canadian farmers to easily adopt when choosing their first insect to farm' (ibid). Similarly, although the 'Big Four' were initially produced to feed exotic pets and zoo animals in EU countries, 'their production for human food simply represents a reassigning of their intended destination' (House 2018: 10).

Since many EU producers utilise 'indoor systems' to foster 'insect growth and development' and have automated farming techniques to optimise production, it is thought that 'the European insect industry is today a world leader in terms of innovation and technological advancement' (Derrien and Boccuni 2018: 473). Nevertheless, 'the reliance on human labour is credited as being a primary driver in keeping insect prices high' (Dossey et al 2016b: 118), even though feeding costs of insects is relatively low (Dobermann et al 2017: 303). However, if farmers adopt smart and robotic technologies to streamline insect production, this will reduce labour costs to make edible insects an increasingly viable alternative for consumers (e.g. Cecchini 2017; McCann 2018). To understand this new 'insect industry' from a less human-centric perspective, it is useful to explore the relationship between insects, techno-science and sustainability culture' (Buiani 2015: 109).

As discussed, edible insects are being framed as a sustainable solution to environmental and global food concerns. If more farmers harness new technologies to hasten the intensification of insect production this may also herald the hyper-'McDonaldization' 
of invertebrate farming in future years (Ritzer 2000). If this occurs, this innovative food sector is likely to

prioritize a new type of instrumental anthropocentrism that aggressively pursues insects through manipulation and re-fabrication in the name of a discourse sustainability - presented as the purpose of the harmonious coexistence between, and balance of, humans and non-humans, yet still profoundly focused on the human (Buiani 2015: 113).

Since the 'doubly other' status of edible insects is likely to minimise people's concerns about farming and killing invertebrate animals, this might expedite the intensification of production and contribute to the unquestioned exploitation of minilivestock (Loo and Sellbach 2013:13). If so, multitudes of farmed insects are destined to become part of the 'silent majority' (Moore 2017: 166). These masses of invertebrate animals are also likely to encounter 'institutional vertebratism' (Leather 2009: 413-414), because legally and politically the welfare and suffering of vertebrate livestock will take precedence over food animals without backbones. Entomophagists have actively rebranded these pesky creatures as bona fide food animals, but the extent to which this cultural makeover also elevates the moral status of insects from 'tiny automata' to productive animals remains to be seen.

Having contextualised the rise of edible insect farming in Europe and North America, the next section will summarise the methods used for this exploratory research. The final section of the paper will then discuss preliminary profile findings derived from 17 semi-structured pilot interviewees to provide a descriptive characterisation of the 'minilivestock' farmers shaping this new food animal sector. 


\section{Methodology}

To the best of my knowledge, this is the first social science study to explore the emergence of edible insect farming in Europe (EU) and North America (NA) from the perspective of insect practitioners. This pilot qualitative research was designed to understand the human-invertebrate productive interface through the experiences, views and feelings of people who have mainly farmed food and/or feeder insects. Having received ethical approval from my institution in August 2016, I conducted 17 semistructured interviews ( 8 via phone and 9 via Skype) with 3 women and 14 men between December 2016 and August 2017. People were recruited by a combination of purposive, convenience and snowball sampling methods: e.g. emailing insect farming companies and start-ups, sending project information to entomological and vertical farming organisations, networking at edible insect workshops/events and interviewees suggesting additional contacts. The interviews lasted on average 90 minutes but ranged from 58 minutes to 3 hours and 48 minutes in length. All interviews were audiorecorded with participant permission and have been fully transcribed. Prior to conducting any interviews all potential participants received study information via email explaining the focus and rationale of the research. All participants signed a consent form and emailed their completed profile surveys prior to being interviewed. Since some interviewees are leading figures or industry experts within this pioneering agricultural sector, all reasonable steps have been taken to safeguard their anonymity (Saunders et al 2015). For example, UK contacts have been subsumed under the EU to minimise identification, and pilot profile data has been aggregated in 4 of the 5 tables below. Preliminary profile findings will now be presented to provide a descriptive characterisation of those spearheading the farming of insects for food. 


\section{Descriptive characterisation of insect farmers in Europe and North America}

[Insert Table 1]

The profile information in Table 1 indicates most interviewees have no farming experience and minimal, if any, entomological knowledge about insect lifecycles and their environmental/dietary requirements. That said, all but one has studied to Degree level, and a substantial number have gained postgraduate qualifications. The undergraduate Degrees include a mix of science and social science disciplines: Agriculture/Zoology, Biology (3), Engineering, English, Ethics, Geography, Geology, Physics, Plant Science, Political Science (2), Political Economy, Psychology, and Theatre. The person without a Degree is 55 years old and has extensive experience of rearing feeder insects in hobby and commercial settings. Although this level of tertiary education is unusual in conventional livestock sectors, it may foster the enterprising spirit of entrepreneurs founding farms in this 'insect industry' (Buiani 2015: 109). In this case, it was mainly men in their late thirties. However, the extent to which this socio-demographic profile represents this farming sector remains to be seen. Most interviewees were also engaged in full/part-time insect-related work, and a few were self-employed. The types of insect work includes: designing insect farming technologies, consultancy, promoting entomophagy, public outreach, farming insects commercially, research/knowledge transfer and cultivating insects for non-farming contexts. The one exception keeps pet insects and works in the public sector.

I will now consider my participants' dietary preferences and leisure lifestyles. These areas were included because entomophagists and insect farmers are typically motivated by environmental and sustainability issues (e.g. 'Insectpreneurs Series'). ${ }^{6}$ 
Given such outlooks how might this influence their dietary decisions? Moreover, since people are often introduced to eating insects when travelling or volunteering overseas was this the case for my contacts too?

\section{[Insert Table 2]}

Insect enthusiasts/farmers often say they first experienced entomophagy whilst travelling abroad (e.g. Wiedemann 2014). Similarly, this finding is evident in Table 2. As Dossey et al explain 'In an age of increased ease of international travel, people have accessed the idea of insects as food through exposure, both virtual and in person, to diverse cultures and new concepts of what can be food' (2016b: 135; Perdue 2018). Half of my contacts self-identified as 'foodies', so are enthusiastic about food-related issues including new dietary trends, and a few NA interviewees reside in communities with an active 'local food scene', 'wholefood movement' that were 'sustainability focussed'. Given such food-centric interests it is perhaps unsurprising that gardening, growing vegetables, sourcing local foods, recycling waste, living healthily and sustainably are high on their list of priorities and leisure activities. Even so, my EU interviewees seem to place more emphasis on ecological and environmental issues than their NA counterparts.

On the other hand, despite expressing concern about the sustainability of existing systems of livestock production, most interviewees continued to consume meat (i.e. 13). Whilst 3 EU contacts did not eat meat two of them noted they eat insects at home. This is an interesting finding that warrants further exploration. Although this was not the focus of my study, it has been suggested that 'Insect-based convenience foods seem better suited for the meat-reducer or 'flexitarian' market, or for 
environmentally-motivated vegetar-ians who do not completely rule out the consumption of some animals' (House 2016: 56). Vegetarians who abstain 'from the consumption of animal flesh with the exception of insects and arachnids' have been called 'entotarians' (Curry 2014). In May 2017, an online blogger called Josh Galt started experimenting with a vegan diet that includes edible insects. He calls this food practice 'entoveganism' and has outlined 'core tenents of the entovegan philosophy'. The extent to which these dietary practices stimulate political and ethical debates about the 'doubly other' status of insects amongst non-insect eating vegetarians and vegans also remains to be seen (e.g. Fischer 2016).

Having discussed preliminary data pertaining to dietary and leisure lifestyles I will now consider interviewees' length of time and reasons for farming insects.

\section{[Insert Table 3]}

Since 12 participants started rearing edible insects following the publication of the Edible Insects Report in 2013, to some extent, this shows how influential this FAO document has been. Although some interviewees no longer farm insects, their pioneering farming experiences continue to shape this emerging 'insect industry' (Buiani 2015: 109). Moreover, despite the preliminary nature of this data and the small sample size, my NA insect farmers seem more likely than EU farmers to rear crickets than mealworms. Another difference between my EU and NA producers are the reasons for rearing insects. As indicated in Table 3 the main reasons proffered by EU interviewees is to feed exotic pets, personal consumption, supply pet shops and design insect production technology. In contrast, NA producers are primarily rearing insects to supply the insect food sector, to make profit and supply zoos. To gain a 
more detailed overview of the contexts, types and scales of insect rearing experiences see Table 4.

[Insert Table 4]

The majority of participants (i.e.13) reared feeder and/or food insects commercially, albeit on various scales. A few contacts had experience of rearing edible species of feeder insects on a mass scale but not to a food-grade standard. That being said, feeder farmers are well placed to transition into the insects-as-food sector as they have the necessary invertebrate husbandry knowledge to do so. In contrast, novice farmers start rearing insects in their basement or garden shed but often lack entomological knowledge about the insect species' lifecycles and environmental/dietary requirements. This knowledge-skills gap means building up viable colonies of insects can be easier said than done. To short-circuit the pitfalls of learning by doing inexperienced farmers are contacting feeder farmers to request farm visits to see how they do it. Given this growing demand, the husbandry skills, knowledge and pragmatic experiences of feeder farmers has become highly valued and eagerly sought after; especially by 'entopreneurs' setting up insect farms, and investors scaling up this food-farming sector (Solon 2015). Since skilled insect practitioners are being inundated with such requests this has generated a mixed response amongst my interviewees: some charge consultancy fees to convey their knowledge, some are very enthusiastic about knowledge transfer, whilst others are opting to 'hold [their] cards close to [their] chests' because it's a 'guarded market' and 'it's a competitive industry out there' (EU interviewee). 
The final profile table provides an overview of how interviewees perceive their roles within this sector and the insects they rear.

\section{[Insert Table 5]}

As shown in Table 5 the majority of interviewees identified with the role of insect farmer, whilst 3 did not. Having considered their profiles, one wondered if 'insect farmer' was formally recognised by governing bodies for taxation purposes, one kept insects as pets, and one had yet to start rearing insects. Irrespective of the experiences of and reasons for farming insects, it is apparent from this pilot research that the perceived status of insects is ambiguous in practice. Although no participants' classified insects as pets (including the person who regarded some of their insects as pets during their interview), ${ }^{8}$ they were often simultaneously regarded as working animals and/or commodities and/or sentient beings, and more atypically as 'my children'. This human-animal theme was explored more fully during the semistructured interviews and will be elaborated on in future publications.

Finally, two-thirds of my contacts regard themselves as an entrepreneur; a role that has been described as 'the real pioneers' within the 'insect-based food space' (Dossey et al 2016b: 135). Spearheading innovative research to develop new business ventures clearly requires funds. Since 'entopreneurs' are often highly educated entomophagists, who ardently believe in the environmental, nutritional and sustainable credentials of insects-as-food, such passion is likely to persuade investors of the 'transformative' nature of their farming-food visions (Dossey et al 2016b: 150). One way of understanding the transformative potential of insect farming is the notion of 'disruptive innovation' which refers to a 'process by which a product or service takes root initially 
in simple applications at the bottom of a market and then relentlessly moves up market, eventually displacing established competitors' (Christensen 2018). To date, common sources of investment have been ascertained via Angel Investors, crowdfunding sites, academic research grants, entrepreneurial competitions and philanthropists such as the Gates Foundation (Shockley et al 2018: 73; Dossey et al 2016b: 150). 'While many industries and food trends are started by large corporations and conglomerates that see potential profits, the edible insect industry was pushed into the mainstream by startups with nothing but passion and the public's support' (Shockley et al 2018: 66).

\section{Conclusion}

A new 'insect industry' is emerging throughout Europe and North America: edible insect farming. Contemporary entomophagy movements have partially fuelled this momentum along with 'first wave' feeder farmers transitioning into this new food market. In this highly competitive and innovative climate experienced 'minilivestock' farmers are particularly well placed to mass-produce human-grade food insects. Moreover, their tacit interspecies knowledge and pragmatic husbandry skills is also like gold dust and has become highly sought after by novice farmers and financial investors. It seems that societies typically characterised by 'institutional vertebratism' are increasingly valuing those who can address the current dearth of invertebrate knowledge, especially in practice.

The ideologically passionate, but entomologically inexperienced, 'entopreneurs' blazing a trail in this pilot study are highly educated men in their late thirties. The extent to which their impassioned visions and practices generate 'disruptive innovation' within 
the conventional livestock sector remains to be seen; especially given the push to increasingly automate insect production. As regulatory-legislative-productive blind spots get clarified, this may attract less ideologically motivated 'minilivestock' farmers who see an opportunity to capitalise on and exploit this new food animal resource. The rebranding of pesky invertebrates clearly heralds a futuristic and ideological vision of 'insects-as-food'. However, their diminished animal status also heralds the largely unquestioned exploitation of multitudes of farmed insects in future years. As members of the 'silent majority' increasingly register on peoples' dietary radar, an opportunity has also arisen for farmers, entomologists, consumers, animal advocates and scholars to critically reflect on, and grapple with, the political and ethical implications raised by the liminal and 'doubly other' status of farmed food insects. 


\section{References}

Barron, Andrew and Colin Klein (2016) What Insects Can Tell Us about the Origins of Consciousness, PNAS, 113(118): 4900-4908

http://www.pnas.org/content/pnas/113/18/4900.full.pdf (accessed 26/8/18)

Beisel, Uli, Ann Kelly and Noemi Tousignant (2013) 'Knowing Insects: Hosts, Vectors and Companions of Science, Science and Culture, 22(1): 1-15.

Belluco, Simone, A, Halloran and A, Ricci, (2017) 'New Protein Sources and Food Legislation: The Case of Edible Insects and EU Law', Food Security, 9(4): 803-814.

Bingham, Nick (2006) 'Bees, Butterflies, and Bacteria: Biotechnology and the Politics of Nonhuman Friendship', Environment and Planning A, 38(3): 483-498.

Buiani, Roberta (2015) 'The Rise of the Insect Industry: Sustainable Potential or Wasteful Accumulation', Technoscienza, 6(1): 109-131.

Bull, Jacob (2014) 'Between Ticks and People: Responding to Nearbys and Contentments, Emotion, Space and Society, 12: 73-84.

Cecchini, Chiara. (2017) 'Edible Innovations: Andrew Brentano Harvests Insects for a 'Smart Farm', Makezine, May 25, https://makezine.com/2017/05/25/edibleinnovations-insects-smart-farm/ (accessed 17/6/18) 
Christensen, Clayton (2018) 'Disruptive Innovation', http://www.claytonchristensen.com/key-concepts/ (accessed 22/6/18)

Clark, Jonathan (2016) 'Which Animals Do We Study?' in Animals in Society Working Group - Why Animal Studies Series? June 27, https://animalsinsocietygroup.wordpress.com/2016/06/27/series-why-animal-studies-

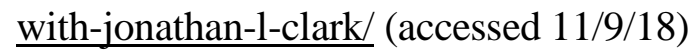

Clegg, A (2015) 'Edible Insect Farms Strive for Scale: Old Production Methods Are Being Rethought to Increase Output of Alternative Food', Financial Times: http://www.ft.com/cms/s/0/b72f9ebe-0f5c-11e5-b968-

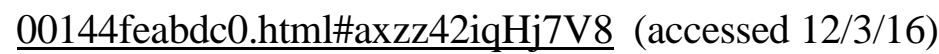

Curry, Meghan (2014) 'What is an Entotarian? Bug Vivant, December 29: http://bugvivant.com/entotarian/ (accessed 16/9/18)

Defoliart, Gene, (1999) 'Insects as Food: Why the Western Attitude is Important', Annual Review of Entomology, 44: 21-50.

DeFoliart Gene (2018) - 'Insects as Food', UW-Madison Department of Entomology http://labs.russell.wisc.edu/insectsasfood/about-dr-defoliart/ (accessed 7/6/18)

DeFoliart, Gene, Florence Dunkel and David Gracer (2009) (eds) 'Sky Prawns and Other Dishes: The Food of the Future' in The Food Insects Newsletter, 5(2): 114. 
De Goede, DM, J Erens, E, Kapsomenou and M Peters, (2013) 'Large Scale Insect Rearing and Animal Welfare' in H. Röcklinsberg and P Sandin (eds) The Ethics of Consumption. Wageningen, The Netherlands: Wageningen Academic Publishers pp. 236-242.

Delgado, Christopher. et al. (1999) Livestock to 2020: The Next Food Revolution. Paper 28. Washington: International Food Policy Research Institute.

Deroy, Ophelia, Ben Reade and Charles Spence, (2015) 'The Insectivore's Dilemma, And How to Take the West out of It', Food Quality and Preference, 44: 44-55.

Derrien, Christopher, and Andrea Boccuni, (2018) 'Current Status of the Insect Producing Industry in Europe', in A, Halloran, Roberto Flore, Paul Vantomme and Nanna Roos (eds) Edible Insects in Sustainable Food Systems. Switzerland: Springer International Publishing. pp. 471- 479.

Dobermann, D, JA, Swift and LM, Field (2017) 'Opportunities and Hurdles of Edible Insects for Food and Feed', Nutrition Bulletin, 42(4): 293-308.

Dossey, Aaron, Juan A Morales-Ramos and M Guadalupe, Rojas (2016a) (eds) Insects As Sustainable Food Ingredients. London: Academic Press. 
Dossey, A, J Tatum and W McGill, (2016b) 'Modern Insect-Based Food Industry: Current Status, Insect Processing Technology, and Recommendations Moving Forward', in Dossey, Aaron, Juan A Morales-Ramos and M Guadalupe, Rojas (eds) Insects As Sustainable Food Ingredients. London: Academic Press. pp. 113-152.

Emel, Jody and Harvey Neo (2015) (eds) Political Ecologies Of Meat. London: Routledge.

English, Peter, Gethyn Burgess, Ricardo Segundo and John Dunne (1992) Stockmanship. Ipswich: U.K: Farming Press.

Erens, J, S, Es Van, F, Haverkort, E, Kapsomenou and A, Luijben (2012) A Bug's Life. Wageningen UR (September-October 2012).

Evans, J, MH Alemu, R Flore, MB Frost, A Halloran, AB Jensen, G Maciel-vergara, VB Meyer-Rochow, C Munke-Svendsen, SB Olsen, C Payne, N Roos, P Rozin, HSG Tan, A, van Huis, P Vantomme and J Eilenberg. (2015) “Entomophagy': An Evolving Terminology In Need of Review', Journal of Insects as Food and Feed, 1(4): 293-305.

Fischer, Bob. (2016) 'Bugging the Strict Vegan', Journal of Agricultural and Environmental Ethics, 29(2): 255-263.

Gjerris, M, C, Gamborg and H, Röcklinsberg, (2016) 'Ethical Aspects of Insect Production for Food and Feed', Journal of Insects as Food and Feed, 2(2): 101-110. 
Halloran, A, N Roos, R Flore, and Y Hanboonsong (2016) 'The Development of the Edible Cricket Industry in Thailand', Journal of Insects as Food and Feed, 2(2): 91-100.

Halloran, Afton, Nanna Roos and Yupa Hanboonsong, (2017) 'Cricket Farming As A Livelihood Strategy In Thailand', The Geographical Journal, 183(1): 112-124.

Hanboonsong, Yupa, Tasanee Jamjanya and Patrick Durst (2013) Six-Legged Livestock. FAO United Nations: Bangkok.

Hardouin, Jacques. (1995) 'Minilivestock: From Gathering to Controlled Production', Biodiversity and Conservation, 4: 220-232.

Holt, V. (1995) Insects - A Victorian Cookery Book. Reissued version of Why Not Eat Insects? Oxford: Thornton's.

House, Jonas (2016) 'Consumer Acceptance Of Insect-based Foods in The Netherlands: Academic and Commercial Implications', Appetite, 107: 47-58.

House, Jonas (2018) 'Insects Are Not 'The New Sushi': Theories of Practice and Acceptance of Novel Foods', Social and Cultural Geography, 1-22 (online first)

Jongema, Yde. (2017) List of Edible Insects of the World (April 1, 2017), Retrieved from https://www.wur.nl/en/Research-Results/Chair-groups/Plant-Sciences/Laboratoryof-Entomology/Edible-insects/Worldwide-species-list.htm (accessed 23/8/18) 
Kagui, Olena (2018) 'Entoveganism: Veganism with a Six-Legged Twist', Woven Network Blog Post: $\quad$ https://woven-network.co.uk/blog/category/standard-posts/ (accessed 11/9/18)

Lawrence, Geoffrey. (2017) 'Re-evaluating Food Systems and Food Security: A Global Perspective', Journal of Sociology, 53(4): 774-796.

Leather, Simon. (2009) 'Institutional Vertebratism Threatens UK Food Security’, Trends in Ecology and Evolution, 24(8): 413-414.

Loo, Stephen and Undine Sellbach. (2013) 'Eating (with) Insects: Insect Gastronomies and Upside-Down Ethics', Parallax, 19: 12-28.

Looy, Heather, Florence Dunkel and John Wood (2014) 'How Then Shall We Eat? Insect-eating Attitudes and Sustainable Foodways', Agriculture and Human Values, 31: $131-141$.

Lunney Daniel (2014) What's in A Name? Well, 'This Ere “Tortis” is A Insect', Animal Studies Journal, 3(1): 46-72.

Martin, Daniella (2014) Edible. Boston: Houghton Mifflin Hardcourt Publishing Company. 
McCann, B, (2018) 'Farming Edible Bugs with Robotics and AI to Alleviate Global Food Insecurity', Opalesque, 11 March, http://www.opalesque.com/horizons/9/farmingedible-bugs-with-robotics-and-ai-to.html (accessed 17/6/18)

Moore, Lisa Jean (2017) Catch and Release: The Enduring yet Vulnerable Horseshoe Crab. New York: New York University.

Müller, A, J, Evans, C Payne, and R Roberts (2016) 'Entomophagy and Power', Journal of Insects as Food and Feed, 2(2): 121-136.

Payne, CL, D Dobermann, A Forkes, J House, A McBride, A Müller, RS Quilliam and S Soares, (2016) 'Insects as Food and Feed: European Perspectives on Recent Research and Future Priorities', Journal of Insects as Food and Feed, 2(4): 269-276.

Perdue, Robert Todd (2018) 'Eating Insects and Tourism: Ethical Challenges in a Changing World' in Kline, Carol (ed) Tourism Experiences and Animal Consumption. London: Routledge (pp. 73-86).

PROteInsect White Paper (2016) Insect Protein - Feed For the Future: http://www.proteinsect.eu/index.php?id=32 (accessed 6/9/18)

Ritzer, George, (2000) The McDonaldization of Society. California: Pine Forge Press.

Rivers, David, (2017) Insects. Baltimore: Johns Hopkins University Press. 
Rozin, P \& Fallon, A (1987) 'A Perspective on Disgust', Psychological Review, 94 (1): 23-41.

Rumpold, Birgit and Oliver K. Schlüter, (2013) 'Potential And Challenges Of Insects As An Innovative Source For Food And Feed Production', Innovative Food Science and Emerging Technologies, 17: 1-11.

Saunders, Benjamin, Jenny Kitzinger and Celia Kitzinger. (2015) 'Anonymising Interview Data: Challenges and Compromise in Practice', Qualitative Research, 15(5): 616-632.

Sexton, Alexandra (2018) 'Eating for the post-Anthropocene: Alternative Proteins and the Biopolitics of Edibility', Transactions of the Institute of British Geographers, online first: https://rgs-ibg.onlinelibrary.wiley.com/doi/epdf/10.1111/tran.12253 (accessed $5 / 9 / 18)$

Shelomi, M, (2015) 'Why We Still Don't Eat Insects: Assessing Entomophagy Promotion Through A Diffusion Of Innovations Framework', Trends in Food Science and Technology, 45(2): 311-318.

Shockley, M, J Lesnik, RN, Allen and A, Muñoz. (2018) 'Edible Insects and Their Uses in North America; Past, Present and Future', in A, Halloran, Roberto Flore, Paul Vantomme and Nanna Roos (eds) Edible Insects in Sustainable Food Systems. Switzerland: Springer International Publishing. pp. 55-79. 
Singer, Peter (2016) Are Insects Conscious? Project Syndicate, May 12:

https://www.project-syndicate.org/commentary/are-insects-conscious-by-peter-singer-

$\underline{\text { 2016-05 }}$ (accessed 26/8/18)

Solon, Olivia (2015) 'Edible Insect-Farming Hatches New Breed of 'Entopreneurs'. Do

Westerners Have The Stomach For Entomophagy?’ Bloomberg, 10 September, https://www.bloomberg.com/news/articles/2015-09-10/edible-insect-farming-hatchesnew-breed-of-entopreneurs- (Accessed 25/9/15)

Taponen, Illka (2018) Entomology Company Database Version 75, https://ilkkataponen.com/entomology-company-database/ (accessed 23/8/18)

Tiffin, Helen (2016) Do Insects Feel Pain? Animal Studies Journal, 5(1): 80-96

van Huis, A., J, van Itterbeeck, H, Klunder, A Halloran, G Muir and P Vantomme (2013) Edible Insects. Rome: FAO

Vantomme, P. (2015) 'Way Forward to Bring Insects in The Human Food Chain', Journal of Insects as Food and Feed, 1(2): 121-129.

Verbeke, Wim. (2015) 'Profiling Consumers Who Are Ready To Adopt Insects As A Meat Substitute in a Western Society', Food Quality and Preference, 39: 147-155.

Waltner-Toews, David. (2017) Eat the Beetles. Toronto: ECW Press. 
Wathes, Christopher, Henry Buller, Heather Maggs and Madeleine Campbell (2013) 'Livestock Production in the UK in the $21^{\text {st }}$ Century: A Perfect Storm Averted', Animals, 3(3): $574-583$.

Wiedemann, Elettra, (2014) 'How American Cricket Farmers Raise Bugs For Us to Eat', Munchies, 14 August: https://munchies.vice.com/en_us/article/nz9x8d/how-americancricket-farmers-raise-bugs-for-us-to-eat (re-accessed 24/6/18)

Wood, John and Heather Looy, (2000) 'My Ant is Coming to Dinner: Culture, Disgust, and Dietary Challenges', Proteus, 17(1): 52-56.

Yates-Doerr, Emily. (2015) 'The World in A Box? Food Security, Edible Insects, And “One World, One Health” Collaboration', Social Science and Medicine, 129: 106-112. 
1 'Entomophagy' is when people eat insects and 'insectivory' is the 'consumption of insects by nonhuman animals' (Evans et al 2015: 294).

2 'Minilivestock' applies to invertebrates if 'used as food, animal feed or as sources of revenue and are kept for one of these purposes by humans' (Hardouin 1995: 221).

${ }^{3}$ Black soldier flies are also used in food waste management.

${ }^{4}$ Four participants produced feed insects (i.e. Table 4).

${ }^{5}$ Farming edible insects is 'a common and millennia old practice in countries such as Thailand, China, Laos, Japan and Mexico' and is becoming an option in Europe and the USA (Vantomme 2015: 125).

${ }^{6}$ 4Ento: https://4ento.com/category/interviews/ (accessed 9/9/18).

7 For more information: https://entovegan.com/entovegan-philosophy/ (accessed 11/9/18). See also Kagui (2018).

${ }^{8}$ This contact reared and ate mealworms and waxworms but 'pet' insects were not consumed (e.g. stick insects and cockroaches). 